\title{
PREPRINT
}

Author-formatted, not peer-reviewed document posted on 10/01/2022

DOI: https://doi.org/10.3897/arphapreprints.e80334

\section{Two new species of the genus Joeropsis (Isopoda, Asellota, Joeropsididae) from Korean waters}

\author{
Sung Hoon Kim, (D) Jong Guk Kim, Seong Myeong Yoon
}

\section{Disclaimer on biological nomenclature and use of preprints}

The preprints are preliminary versions of works accessible electronically in advance of publication of the final version. They are not issued for purposes of botanical, mycological or zoological nomenclature and are not effectively/validly published in the meaning of the Codes. Therefore, nomenclatural novelties (new names) or other nomenclatural acts (designations of type, choices of priority between names, choices between orthographic variants, or choices of gender of names) should NOT be posted in preprints. The following provisions in the Codes of Nomenclature define their status:

International Code of Nomenclature for algae, fungi, and plants (ICNafp)

Article 30.2: "An electronic publication is not effectively published if there is evidence within or associated with the publication that its content is merely preliminary and was, or is to be, replaced by content that the publisher considers final, in which case only the version with that final content is effectively published." In order to be validly published, a nomenclatural novelty must be effectively published (Art. 32.1(a)); in order to take effect, other nomenclatural acts must be effectively published (Art. 7.10, 11.5, 53.5, 61.3, and 62.3).

International Code of Zoological Nomenclature (ICZN)

Article: 21.8.3: "Some works are accessible online in preliminary versions before the publication date of the final version. Such advance electronic access does not advance the date of publication of a work, as preliminary versions are not published (Article 9.9)". 
1 Running title: Two new Joeropsis from South Korea

2

Two new species of the genus Joeropsis (Isopoda, Asellota, Joeropsididae) from Korean waters

\section{Sung Hoon Kim¹, Jong Guk Kim², Seong Myeong Yoon ${ }^{3,4}$}

1 Division of Ocean Sciences, Korea Polar Research Institute, Incheon 21990, Korea

2 Marine Ecosystem Research Center, Korea Institute of Ocean Science and Technology, Busan 49111, Korea 3 Department of Biology, College of Natural Sciences, Chosun University, Gwangju 61452, Korea 4 Educational Research Group for Age-associated Disorder Control Technology, Graduate School, Chosun University, Gwangju 61452, Korea

Corresponding author: Seong Myeong Yoon (smyun@chosun.ac.kr)

\section{Abstract}

Two new species, Joeropsis denticulatus sp. nov. and Joeropsis semicircularis sp. nov. are reported from South Korea. Joeropsis denticulatus sp. nov. differs from its congeners by the following features: (1) whole body has chromatophores dorsally, although those in pereonite $\mathrm{V}$ occasionally are faint or lacking according to individuals; (2) lateral margins of the cephalon are smooth and narrowing anteriorly; (3) the distal end of the pseudorostrum is round; (4) maxillipedal palp article II has a mesial lobe bifid distally; and (5) basis of pereopods have serrated cuticular scales superiorly. Joeropsis semicircularis sp. nov. can be distinguishable from other Joeropsis species by the following characteristics: (1) the cephalon, pereonite IV, and pleotelson have dark brown chromatophores dorsally; (2) lateral margins of the cephalon are smooth and parallel each other; (3) the distal end of the pseudorostrum is round and slightly serrate; (4) flagellar article I of the antenna is swollen and semicircular-shaped; and (5) the pleotelson and uropods are serrated on lateral margins.

Keywords: isopods, Joeropsis, morphology, new species, South Korea, taxonomy 


\section{Introduction}

The genus Joeropsis Koehler, 1885 including 81 species is the largest genus in the family Joeropsididae Nordenstam, 1933 (Boyko et al. 2008). This genus can be distinguished from other joeropsidid genera by having a laterally parallel body shape, a dorsally smooth or finely granular body surface, and a not medially expanded maxillipedal palp article III (Just 2001; Bruce 2015). In the Joeropsis taxonomy, the colour pattern of the body has been regarded as an important character to discriminate Joeropsis species, but it still has several issues: (1) many species share a similar colour pattern; (2) occasionally, the pattern faints for old preserved specimen; and (3) the pattern shows variable character states according to individuals in several species (Menzies, 1951; Bruce, 2015). Bruce (2015) has recently mentioned that shapes of the cephalon, pseudorostrum, maxilliped, pleotelson, male pleopod I, and uropod can be useful diagnostic characters in this genus.

Although Joeropsis species are known to be distributed worldwide, they are well represented in tropical regions such as the Indo-West Pacific and ubiquitous in coral reef habitats (Bruce 2009, 2015). In the temperate Far East, only three species have been recorded: J. affinis Kussakin, 1961 from Russia; J. lata Kussakin, 1961 from Russia; and J. latiantennata Nunomura, 1999 from Japan (Kussakin 1961; Nunomura 1999; Just 2001; Kensley and Schotte 2002; Kazmi and Yousuf 2003; Kensley 2003). During surveys of Korean isopods, the authors found two unknown Joeropsis species from sublittoral habitats. Here, we provide detailed descriptions and illustrations of these species, named Joeropsis denticulatus sp. nov. and $J$. semicircularis sp. nov. In the present paper, we focused on the morphology of the pseudorostrum, cephalon, maxillipedal palp, pleotelson, and pleopod I rather than the colour pattern of the body to discriminate Joeropsis species. This is the first report of Joeropsis from Korean waters.

\section{Materials and methods}

Materials of $J$. denticulatus sp. nov. and $J$. semicircularis sp. nov. were collected from sublittoral zones of Korean waters using a Smith-McIntyre grab and SCUBA diving. Collected materials were sorted using a sieve with a $1 \mathrm{~mm}$ mesh size and immediately fixed with $94 \%$ ethyl alcohol. After transferring these materials to the 
laboratory, observation was conducted under a dissecting microscope (Olympus SZH-ILLD) and a compound microscope (Olympus BX50). Measurements and drawings of specimens were carried out with the aid of a drawing tube. Drawings were digitally scanned, inked, and arranged using a tablet and Adobe Illustrator CS6 as described by Coleman $(2003,2009)$. Examined materials in this study were deposited at the National Institute of Biological Resource (NIBR) and Chosun University in South Korea.

\section{Taxonomy}

Order Isopoda Latreille, 1817

Suborder Asellota Latreille, 1802

Family Joeropsididae Nordenstam, 1933

Genus Joeropsis Koehler, 1885

Joeropsis denticulatus sp. nov.

Figures 1A, 2-4

Material examined. Holotype: South Korea $11 \widehat{\partial}(5 \mathrm{~mm})$; Jeju-do, Jeju-si, Chujamyeon, Chujado Island; 3355'18"N, 126¹9'27"E; 20 m; 17 Apr. 2019; SmithMcIntyre grab; NIBRIV0000862803.

Paratypes: $2 \hat{\partial} \hat{O}, 2$ 우; same data as for holotype; NIBRIV0000000000. Additional material. South Korea 1 त ; Jeju-do, Jeju-si, Udo-myeon, Udo Island;

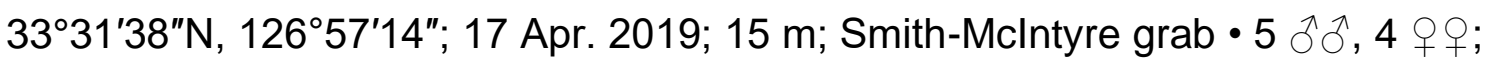

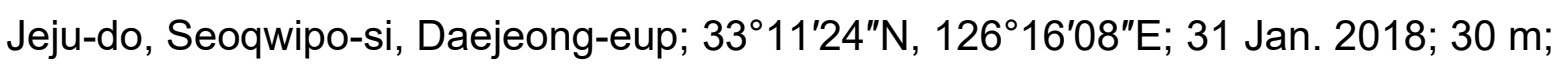
Smith-McIntyre grab; NIBRIV0000862803 1 i; Jeollanam-do, Sinan-gun, Jangsanmyeon, Baegyado Island; $34^{\circ} 22^{\prime 2} 24^{\prime \prime N}, 126^{\circ} 00^{\prime} 15^{\prime \prime E}$; 12 Apr. 2018; 10 m; SCUBA diving 1 ; ; Jeollanam-do, Yeosu-si, Samsan-myeon, Sangbaeckdo Island; $34^{\circ} 03^{\prime} 15^{\prime \prime} \mathrm{N}, 127^{\circ} 35^{\prime} 00^{\prime \prime} \mathrm{E} ; 15 \mathrm{~m}$; 28 Jun. 2017; SCUBA diving.

Etymology. The specific name, denticulatus, originates from the Latin word denticulatus, meaning "with small teeth". This name refers to pereopods possessing serrated cuticular scales.

Description of holotype male. Body (Figs. 1A, 2A) almost $3.9 \times$ longer than wide; dorsal surface matt and smooth, without setae. Cephalon $0.7 \times$ as long as 
wide; lateral margins narrowing anteriorly; eyes positioned sublaterally, globular, dark brown, dorsally bulging. Pseudorostrum (Fig. 2B) $0.7 \times$ as long as proximal wide, rounded anteriorly. Pereonites not compact; lateral margins smooth. Pleotelson $\sim 1 \times$ longer than greatest wide, shield-shaped, tapering distally; caudomedial lobe subacute, tapering distally; lateral margins slightly convex, with eight spines.

Antennula (Fig. 2C) consisting of six articles; article I rectangular, $1.4 \times$ longer than wide, with serrated cuticular scales distally, five simple setae along with lateral margin, one penicillate seta distally, and five penicillate setae mesially; article II oblong, $0.5 \times$ as long as article I, with two simple setae and two penicillate setae distally, and cuticular scales laterally; article III oblong, $0.6 \times$ as long as article II, with two simple setae laterally and three simple setae distally; article IV almost $0.5 \times$ as long as article III, with one penicillate seta and one simple seta distally; article $\mathrm{V} \sim 2$ $\times$ longer than article IV, with two simple setae and two aesthetascs distally, and one simple seta laterally; article VI minute, with four simple setae, one penicillate seta, and one aesthetasc on distal end. Antenna (Fig. 2D) consisting of six peduncular articles and ten flagellar articles; peduncular article III with one process on inner margin; article $\mathrm{V} 1.4 \times$ longer than articles I-IV combined, with serrated outer cuticular scales and one inner process proximally; article VI $0.7 \times$ as long as article $\mathrm{V}$, widening distally, with serrated cuticular scales, three penicillate setae, and several simple setae on distal end; flagellum with numerous simple setae; flagellar article I elongated oval, $1.8 \times$ longer than remaining articles combined, $1.3 \times$ longer than peduncular article $\mathrm{VI}$, with cuticular scales laterally.

Mandibles (Fig. 2E, F), molar process distal half finely serrated; incisor with five cusps; palp article II with serrate setae distally; palp article III with serrate setae along with lateral margin. Left mandible (Fig. 2E) with a protrusion between incisor and molar process; spine row composed of twelve serrate setae. Right mandible (Fig. 2F), spine row consisting of ten serrate setae. Maxillula (Fig. 2G), inner lobe with three robust simple setae and several fine setae distally; outer lobe with twelve strongly serrate robust setae and several fine setae on distal region. Maxilla (Fig. $2 \mathrm{H}$ ), inner lobe shorter than other lobes, with four simple setae distally and fine setae along with inner margin; mesial and outer lobes with four serrate setae distally. Maxilliped (Fig. 2I), endite expanding half of palp article IV, with several short simple setae on mesial surface and two coupling hooks on inner distal end; distal region of 
endite rounded and serrated while concave mesially, with four mesial tubercular robust setae; palp article I with two simple setae distally, article II $2.8 \times$ longer than article I, bifid on inner distal end, article III square, $0.4 \times$ as long as article II, with several simple setae distally, article IV $3 \times$ longer than article III, with fine setae on inner margin and several setae laterally, article $\mathrm{V} 0.2 \times$ as long as article IV, with several simple setae on distal end; epipod $3.4 \times$ longer than basal wide, tapering distally.

Pereopods (Fig. 3A-G), basis and ischium with serrated cuticular scales superodistally; carpus with slightly serrated cuticular scales inferodistally; propodus with 2-4 robust setae inferiorly and numerous short simple setae along with inferior margin. Pereopod I (Fig. 3A), basis with one penicillate seta superiorly; ischium subequal to basis in length, narrowing proximally; merus $0.6 \times$ as long as ischium; carpus $1.7 \times$ longer than merus; propodus $0.9 \times$ as long as carpus, with one penicillate seta on superior distal angle; dactylus $0.2 \times$ as long as propodus, with two claws and one penicillate seta distally. Pereopods II-VII (Fig. 3B-G) similar to each other; basis longer than ischium, with 0-2 penicillate setae on superior margin; ischium convex superomesially; carpus $\sim 2 \times$ longer than merus, with one penicillate seta superodistally; propodus similar to carpus in length, with one penicillate seta superodistally; dactylus $\sim 0.2 \times$ as long as propodus, with three claws distally.

Pleopod I (Fig. 4A) $2.6 \times$ longer than greatest wide, slightly concave laterally, narrowing distally, with projected region on distolateral margins; apex rounded, with marginal simple setae distally. Pleopod II (Fig. 4B), protopod $2.7 \times$ longer than midwide, sinuous laterally bearing cuticular scale-setae distally, with subacute distal end; endopod positioned at 0.7 length of protopod proximally, exopod curved outwardly, appendix masculina reaching to distal end of protopod, tapering distally. Pleopod III (Fig. 4C), endopod $2.1 \times$ longer than wide, with three plumose setae distally; exopod with cuticular scale-setae along with lateral margin, first article $3.8 \times$ longer than wide; second article $0.4 \times$ longer first article. Pleopod IV (Fig. 4D), endopod $2.2 \times$ as long as wide, tapering distally; exopod vestigial. Pleopod V (Fig. 4E) without exopod; endopod $2 \times$ as long as wide, tapering distally.

Uropods (Figs. 2A, 4F), protopod extending beyond margin of pleotelson, with strongly produced distal end, serrated mesial margin, and five simple setae on distal 
region; endopod with two penicillate setae and several simple setae distally; exopod smaller than endopod, with several simple setae distally.

Description of female. Female similar to male except for

pleopod II. Pleopod II (Fig. 4G) $1.4 \times$ longer than greatest width, tapering distally, with fine setae on distal region; apex subacute, with two simple setae.

Colour pattern. Whole body is covered with dark brown chromatophores (Figs. $1 \mathrm{~A}, 2 \mathrm{~A})$.

Variation. The colour pattern of the body is variable according to individuals, especially on pereonite V. Dark brown chromatophores are occasionally faint or not observable on it.

Distribution. South Korea (present study).

Remarks. According to Bruce (2015), the new species, J. denticulatus sp. nov. is similar to 10 of 81 known Joeropsis species or subspecies by having the laterally smooth cephalon, distally round pseudorostrum, mesially lobed maxillipedal palp article II, laterally serrated pleotelson, and mesially serrated uropod: J. adusta Bruce, 2015; J. affinis Kussakin, 1961; J. antillensis Müller, 1993; J. brevicornis brevicornis Koehler, 1885; J. dubia dubia Menzies, 1951; J. dubia paucispinis Menzies, 1951; J. faurei Müller, 1991; J. gertrudae Müller, 1989; Joeropsis latiantennata Nunomura, 1999; and J. stebbingi Kensley, 1975 (Koehler 1885; Menzies 1951; Amar 1961; Kussakin 1961, 1999; Kensley 1975; Müller 1989, 1991, 1993; Nunomura 1999; Bruce 2015). Among them, J. denticulatus sp. nov. most resembles J. dubia dubia in terms of variable colour pattern, anteriorly narrowing lateral margins in cephalon, and bifid mesial lobe in maxillipedal palp article II, but the former can be distinguishable from the latter by having pereopods bearing serrated cuticular scales on the basis (vs. lacking serrated cuticular scales in the latter) and distally rounded pleopod I in males (vs. distally triangular in the latter) (Menzies 1951; Kussakin 1999). The new species can be distinguished from the remaining ten species in terms of maxillipedal palp article II (having distally bifid mesial lobe vs. having not in the latter) and pereopods (having serrated cuticular scales on the basis in the former vs. lacking in the latter) (Koehler 1885; Menzies 1951; Amar 1961; Kussakin 1961, 1999; Kensley 1975; Müller 1989, 1991, 1993; Nunomura 1999; Bruce 2015).

\section{Joeropsis semicircularis sp. nov.}


Figures 1B, 5-7

Material examined. Holotype: South Korea • 1 ๙ (3.7 mm); Jeju-do, Jeju-si, Chujamyeon, Chujado Island; 3359'08"N, 126¹9'08"E; 10 m; 06 Jul. 2019; SCUBA diving; NIBRIV0000862804.

Paratypes: 2 $\widehat{\delta}, 2$ 우, same data as holotype; NIBRIV0000000000.

Additional material. South Korea • 1 đ̧; Jeollanam-do, Sinan-gun, Heuksan-myeon, Hondo-ri, Hongdo Island; 3440'09"N, 125¹0'59"E; 10 m; 19 Jun. 2018 • 1 ô, 1 o; Jeollanam-do, Yeosu-si, Samsan-myeon, Sangbaeckdo Island; 3403'15"N, $127^{\circ} 35^{\prime} 00 " \mathrm{E} ; 15 \mathrm{~m}$; 28 Jun. 2017 • 1 ○े, 4 ㅇ; ; Gyeongsangbuk-do, Ulleung-gun, Buk-myeon, Cheonbu-ri, Gwaneumdo Island; 37³2'43"N, 13055'22"E; 20 m; 19 Jun. 2016; SCUBA diving.

Etymology. The specific name, semicircularis, originates from the combination of Latin words semis, meaning "a half", and circularis, meaning "round". This name refers to the first flagellar article of the antenna that is semicircular-shaped.

Description of holotype male. Body (Figs. 1B, 5A) almost $4.4 \times$ longer than wide; dorsal surface matt and smooth, without setae. Cephalon $0.8 \times$ as long as wide; lateral margins parallel. Pseudorostrum (Fig. 5B) $0.7 \times$ as long as proximal wide, round and rough distally; eye positioned sublaterally, bulging. Pereonites not compact, widely spaced, with smooth lateral margins. Pleotelson (Fig. 5C) $1.1 \times$ longer than wide, almost globular, tapering on posterior region; lateral margin with spines and simple setae; caudomedial lobe rounded distally.

Antennula (Fig. 5D) composed of six articles; article I square to globular, with cuticular scales along with outer margin; article II subsquare, $0.3 \times$ as long as article I, with three penicillate setae, two simple setae, and serrated cuticular scales distally; article III $0.8 \times$ as long as article II; article IV $0.6 \times$ as long as article III, with one penicillate seta distally; article V $1.8 \times$ longer than article IV, with simple setae distally; article VI minute, with two aesthetascs and simple setae on distal end. Antenna (Fig. 5E) composed of 6 peduncular articles and 5 flagellar articles; peduncular article III with one process on inner margin, article $\mathrm{V}$ about $1.7 \times$ longer than articles I-IV combined, with cuticular scales laterally, two simple setae and two penicillate setae distally; article VI $0.7 \times$ as long as article V, with cuticular scales along with distolateral margin; flagellum with numerous simple setae; flagellar article 
230 I semicircular, $3.8 \times$ longer than flagellar articles II-V combined, $1.3 \times$ longer than peduncular article VI, with cuticular scales on convex margin.

Mandibles (Fig. 5F, G), molar process distal half finely serrate; spine row with eleven serrate setae in left mandible but ten in right mandible and incisor with five cusps; palp article II with six serrate setae distally, article III with ten serrate setae along with lateral margin. spine row with eleven serrate setae. Maxillula (Fig. $5 \mathrm{H}$ ) inner lobe with three robust simple setae and several fine setae distally; outer lobe with twelve strongly serrate robust setae and two simple setae distally. Maxilla (Fig. $5 \mathrm{I})$, inner lobe shorter than two outer lobes, with four simple setae distally and several fine setae laterally; mesial and outer lobes with four serrate setae on distal end, respectively. Maxilliped (Fig. 5J), endite, almost $1.1 \times$ longer than greatest width, reaching proximal third of palp article IV, truncated distally; distal margin with four tubercular robust and two short simple setae medially; inner margin with three coupling hooks distally; palp article II $2.4 \times$ longer than article I, distomedial margin produced, with three simple setae distally; article III almost $0.5 \times$ as long as article II, with three setae distally; article IV $1.4 \times$ longer than article III, $2.8 \times$ as long as wide, tapering distally, with four simple setae distally and one simple seta laterally; article $\mathrm{V}$ minute, with six simple setae distally; epipod $\sim 4.3 \times$ longer than basal width; tapering distally; apex subacute.

Pereopods (Fig. 6A-G), basis and ischium with cuticular scales on superodistal end; carpus with cuticular scales inferodistally and numerous short simple setae on inferodistal end; propodus with 2-4 robust setae and numerous short simple setae along with inferior margin. Pereopod I (Fig. 6A), basis $2.7 \times$ longer than wide, with one simple seta on inferior margin; ischium $0.8 \times$ as long as basis; merus $0.6 \times$ as long as ischium, narrowing proximally; carpus $1.6 \times$ longer than merus; propodus 1.2 $\times$ longer than carpus, with one penicillate seta superiorly; dactylus $0.3 \times$ as long as propodus, with two claws on distal end. Pereopods II-VII (Fig. 6B-G) similar to each other; basis with penicillate setae and simple setae on both lateral margins; ischium $\sim 0.8 \times$ as long as basis, convex on superior margin; merus $0.6 \times$ as long as ischium, tapering proximally; carpus subequal to propodus in length, with penicillate setae superodistally; propodus with one penicillate seta on superior margin; dactylus with three claws and few simple setae distally. 
Pleopod I (Fig. 7A) $2.3 \times$ longer than greatest wide; lateral margins concave, pointed on distal region; apical lobe rounded, with several simple setae. Pleopod II (Fig. 7B), protopod $2.3 \times$ longer than greatest wide, concave on subapical region, acute distally, with several fine setae on subapical region; endopod positioned at 0.6 length of protopod proximally, exopod curved outwardly; appendix masculina acute, extending to apex of protopod. Pleopod III (Fig. 7C), endopod $2.1 \times$ longer than midwide, with three plumose setae distally; exopod composed of two articles, with cuticular scale-setae along with lateral margin, subacute distally. Pleopod IV (Fig. 7D), endopod $1.5 \times$ longer than greatest wide, truncated distally; exopod vestigial. Pleopod V (Fig. 7E) without exopod; endopod $1.9 \times$ longer than basal wide, truncated distally.

Uropods (Figs. 5A, 7F), protopod extending to distal end of pleotelson, inner margin slightly serrated; mesiodistal end strongly produced and acute, with three simple dorsal setae; endopod with one penicillate seta and several simple setae distally; exopod smaller than endopod, with several long simple setae distally.

Description of female: Female similar to male except for pleopod II. Pleopod II (Fig. 7G) $1.2 \times$ longer than greatest wide, globular, narrowing proximally, tapering distally; apex broadly rounded, with two simple setae apically.

Colour pattern. The cephalon is covered with dark brown chromatophores distinctly. Pereonite IV and pleotelson are also covered with chromatophores, but indistinct (Figs. 1B, 5A).

Variation. The colour pattern of chromatophores varies according to individuals. Dark brown chromatophores are always distinct on the cephalon, but sometimes they are considerably indistinct on pereonite IV or pleotelson.

Distribution. South Korea (present study).

Remarks. Joeropsis semicircularis sp. nov. can be distinguished from its congeners by the following features: (1) the body has dark brown chromatophores on the cephalon, pereonite IV, and pleotelson; (2) lateral margins of the cephalon are smooth and parallel; (3) the pseudorostrum is slightly serrated distally; (4) the first flagellar article of the antenna is swollen and semicircular-shaped; and (5) the pleotelson and uropod are serrated laterally.

Among genus Joeropsis, the new species resembles six known species by having the cephalon laterally smooth and parallel, the pseudorostrum not concave or 
pointed distally, maxillipedal palp article II lacking mesial lobe, and the pleotelson and uropods both laterally serrated: J. brevicornis brevicornis Koehler, 1885; J. brevicornis littoralis Amar, 1949; J. dollfusi Norman, 1899; J. latiantennata Nunomura, 1999; J. stebbingi Kensley, 1975; and J. wolffi Müller, 1991 (Koehler 1885; Norman 1899; Amar 1961; Kensley 1975; Müller 1991; Nunomura 1999). Among these species, J. semicircularis sp. nov. is most similar to J. latiantennata by having swollen and semicircular-shaped first flagellar article of the antenna (Nunomura 1999). However, the former differs from the latter by the following characteristic features: (1) the dactylus of pereopods II-VII has three claws (vs. two claws in the latter); (2) the second peduncular article of the antenna has a process on inner margin (vs. has not in the latter); and (3) the fourth peduncular article of the antenna is not serrated (vs. serrated in the latter) (Nunomura 1999). The new species can be easily distinguishable from the remaining five species by having swollen and semicircular-shaped first antennal flagellar article (Koehler 1885; Norman 1899; Amar 1961; Kensley 1975; Müller 1991).

\section{Key to known Joeropsis species in the Far East}

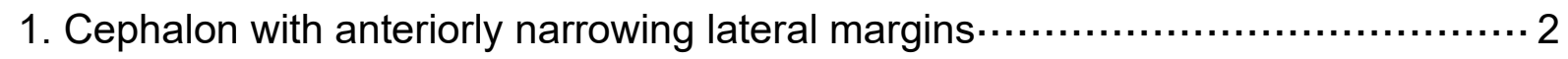

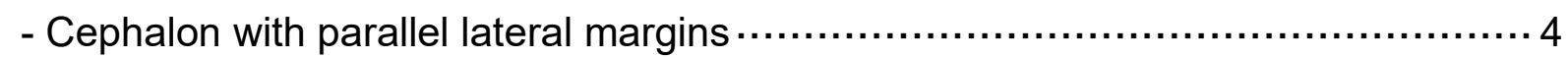

2 Lateral margins of cephalon serrated ….......................................... lata

- Lateral margins of cephalon not serrated

3. Antennal peduncular articles III and V each with a process on inner margin ...........

- Antennal peduncular articles III and $\mathrm{V}$ without any processes ….............. J. affinis

4. Peduncular article $V$ of antenna serrated on outer margin ............. J. latiantennata - Peduncular article $V$ of antenna not serrated on outer margin

J. semicircularis sp. nov.

\section{Acknowledgements}

This study was supported by the research funds from Chosun University (2021) and the National Institute of Biological Resources (NIBR), funded by the Ministry of Environment (MOE) of the Republic of Korea (201902204). 


\section{References.}

Amar R (1961) Jaeropsis mediterranea nov. sp. (isopode asellote) et les Jaeropsis méditerranéennes. Recueil des Travaux de la Station marine d'Endoume 23(37): 121-129.

Boyko CB, Bruce NL, Hadfield KA, Merrin KL, Ota Y, Poore GCB, Taiti S, Schotte M, Wilson GDF [Eds] (2008 onwards) World Marine, Freshwater and Terrestrial Isopod Crustaceans database. Joeropsis Koehler, 1885. Accessed through: http://www. marinespecies.org/isopoda/aphia.php?p=taxdetails\&id=118369 [accessed 06 January 2022]

Bruce NL (2009) A new species of Joeropsis Koehler, 1885 (Isopoda, Asellota, Joeropsididae) from the Great Barrier Reef, Australia. Crustaceana 82(7): 803813. https://doi.org/10.1163/156854009x427351

Bruce NL (2015) Joeropsididae Nordenstam, 1933 (Crustacea, Isopoda, Asellota) from the Lizard Island region of the Great Barrier Reef, Queensland, Australia. ZooKeys 491: 1-62. https://doi.org/10.3897/zookeys.491.4932

Coleman CO (2003) "Digital inking": How to make perfect line drawings on computers. Organisms Diversity and Evolution 3(4): 1-14. https://doi.org/10.1078/1439-6092-00081

Coleman CO (2009) Drawing setae the digital way. Zoosystematics and Evolution 85(2): 305-310. https://doi.org/10.1002/zoos.200900008 Just J (2001) Bathyal Joeropsididae (Isopoda: Asellota) from south-eastern Australia, with description of two new genera. Memoirs of Museum Victoria 58(2): 297-333. https://doi.org/10.24199/j.mmv.2001.58.16

Kazmi BQ, Yousuf F (2003) A new species of Joeropsis (Isopoda, Asellota, Joeropsidae) from a Sabellid reef in Pakistani waters (northern Arabian Sea). Bulletin of Marine Sciences and Fisheries, Kochi University 22: 81-87. Kensley BF (1975) Five species of Jaeropsis from the southern Indian Ocean (Crustacea, Isopoda, Asellota). Annals of the South African Museum 67: 367380.

Kensley BF (2003) Marine isopod crustaceans from Easter Island. Pacific Science, 57(3) 287-317. https://doi.org/10.1353/psc.2003.0023 
Kensley BF, Schotte M (2002) New species and records of Asellota from the Indian Ocean (Crustacea: Peracarida: Isopoda). Journal of Natural History 36(12): 1421-1461. https://doi.org/10.1080/00222930110050401

Koehler R (1885) Description d'un Isopode nouveau, le Joeropsis brevicornis. Annales des Sciences Naturelles (Paris) Zoologie 6: 1-7.

Kussakin O (1961) Representatives of the family Jaeropsidae (Crustacea, Isopoda, Asellota), new for the USSR fauna in the eastern seas. Zoologiscki Zhurnal 40(5): 666-675.

Kussakin OG (1999) Marine and brackish-water Crustacea (Isopoda) of cold and temperate) waters of the Northern Hemisphere. Part 3. Suborder Asellota 2. Families Joeropsididae, Nannoniscidae, Desmosomatidae, Macrostylidae. National Academy of Sciences, USSR, Zoology (Opredeliteli po Faune SSR, Akademiya Nauk, SSSR) 169: 1-384

Menzies RJ (1951) New marine isopods, chiefly from northern California, with notes on related forms. Proceedings of the United States National Museum 101: 105$156 \mathrm{https}: / /$ doi.org/10.5479/si.00963801.101-3273.105

Müller HG (1989) Joeropsidae from Bora Bora and Moorea, Society Islands, with descriptions of four new species (Isopoda: Asellota). Bijdragen tot de Dierkunde 59(2): 71-85. https://doi.org/10.1163/26660644-05902002

Müller HG (1991). Coral-reef inhabiting Joeropsidae from Reunion Island, southern Indian Ocean. Senckenbergiana Biologica, 71(1): 155-168.

Müller HG (1993) Marine Janiroidea from Martinique, French Antilles, with descriptions of a new genus and four new species (Crustacea: Isopoda). Cahiers de Biologie marine 34: 433-460.

Norman AM (1899) Jaeropsis dollfusi, a new Mediterranean isopod. The Annals and Magazine of Natural History, series 7 3: 290-292.

https://doi.org/10.1080/00222939908678200

Nunomura N (1999) Sea shore isopod crustaceans from Izu Islands, middle Japan. Bulletin of the Toyama Science Museum 22: 7-38. 


\section{Figure legends}

389 Figure 1. Photographs of two new species A Joeropsis denticulatus sp. nov., dorsal view $\mathbf{B}$ Joeropsis semicircularis sp. nov., dorsal view. Scale bars: $A=10 \mathrm{~mm} B=5$ $\mathrm{mm}$.

392 Figure 2. Joeropsis denticulatus sp. nov., holotype, male A habitus dorsal view B 393 pseudorostrum $\mathbf{C}$ antennula $\mathbf{D}$ antenna $\mathbf{E}$ left mandible $\mathbf{F}$ right mandible $\mathbf{G}$ maxillula $394 \mathbf{H}$ maxilla I maxilliped. Scale bars: $A=1 \mathrm{~mm} \mathrm{C}-\mathrm{I}=0.2 \mathrm{~mm} \mathrm{~B}=0.05 \mathrm{~mm}$.

395 Figure 3. Joeropsis denticulatus sp. nov., holotype, male A pereopod I B pereopod 396 II C pereopod III D pereopod IV E pereopod V F pereopod VI G pereopod VII. Scale 397 bar $=0.2 \mathrm{~mm}$.

398 Figure 4. Joeropsis denticulatus sp. nov., holotype, male A pleopod I B pleopod II C 399 pleopod III D pleopod IV E pleopod V G uropod. Paratype, female: F pleopod II. 400 Scale bars: $A-E, G=0.2 \mathrm{~mm} \mathrm{G}=0.1 \mathrm{~mm}$.

401 Figure 5. Joeropsis semicircularis sp. nov., holotype, male A habitus, dorsal view B pseudorostrum $\mathbf{C}$ lateral margin of pleotelson $\mathbf{D}$ antennula $\mathbf{E}$ antenna $\mathbf{F}$ left mandible

$403 \mathbf{G}$ right mandible $\mathbf{H}$ maxillula I maxilla $\mathbf{J}$ maxilliped. Scale bars: $\mathbf{A}=0.5 \mathrm{~mm} \mathbf{C}-\mathbf{J}=0.2$ $404 \mathrm{~mm} \mathrm{~B}=0.05 \mathrm{~mm}$.

405 Figure 6. Joeropsis semicircularis sp. nov., holotype, male A pereopod I B 406 pereopod II C pereopod III D pereopod IV E pereopod V F pereopod VI G pereopod 407 VII. Scale bar $=0.2 \mathrm{~mm}$.

408 Figure 7. Joeropsis semicircularis sp. nov., holotype, male A pleopod I B pleopod II 409 C pleopod III D pleopod IV E pleopod V F uropod. Paratype, female G pleopod II. 410 Scale bars: $A-G=0.1 \mathrm{~mm}$. 


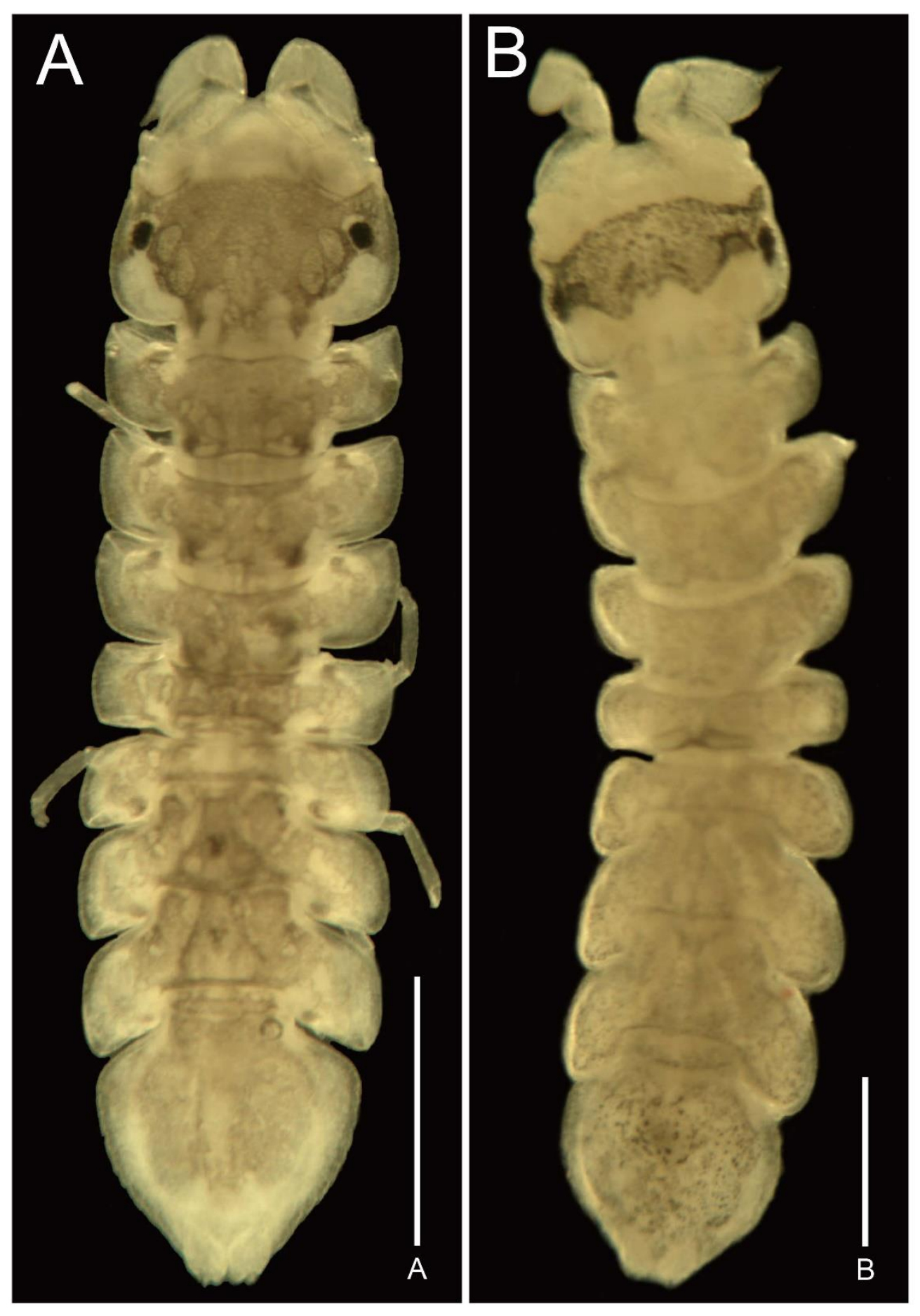

Fig. 1. Kim et al., 2022 


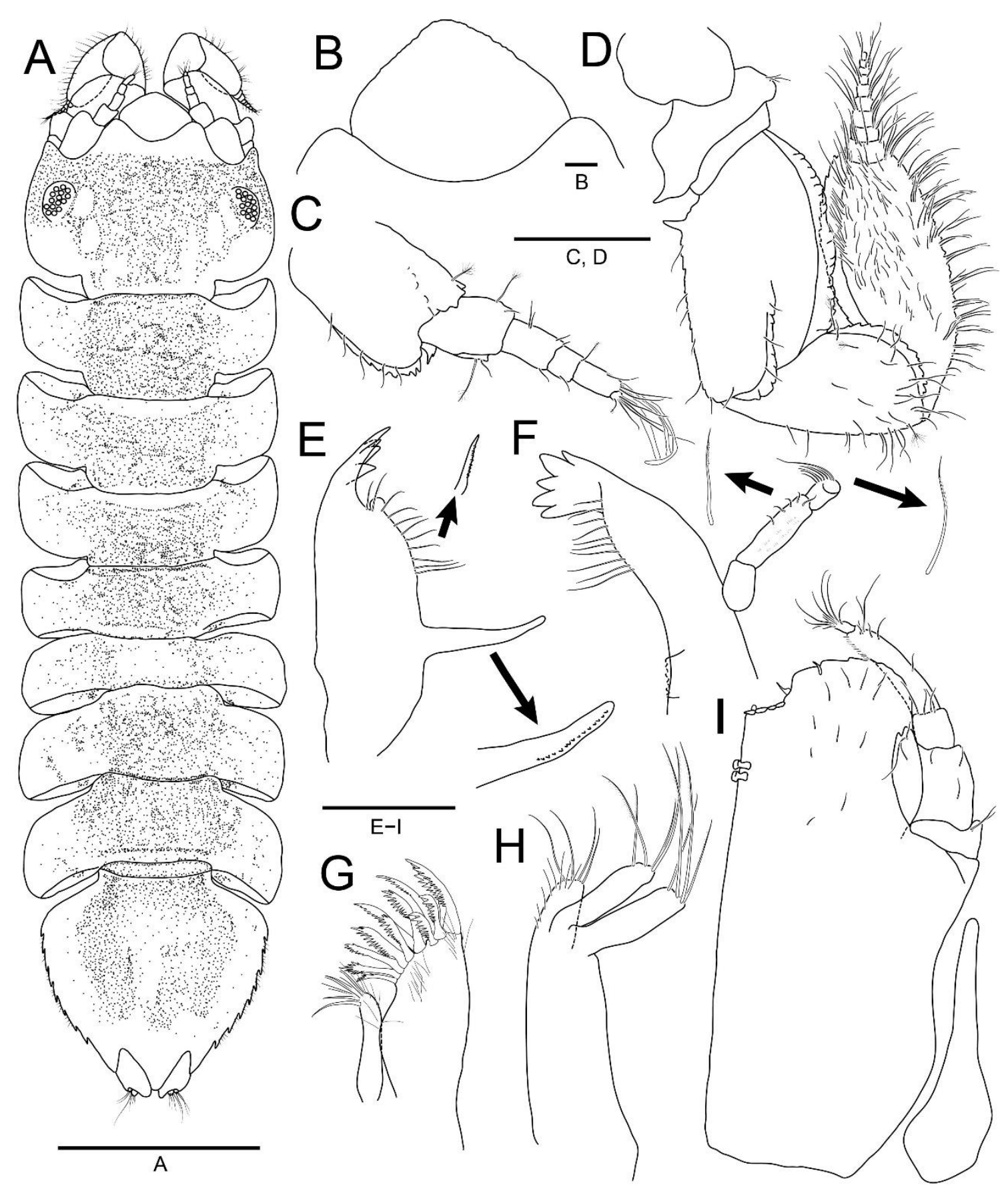




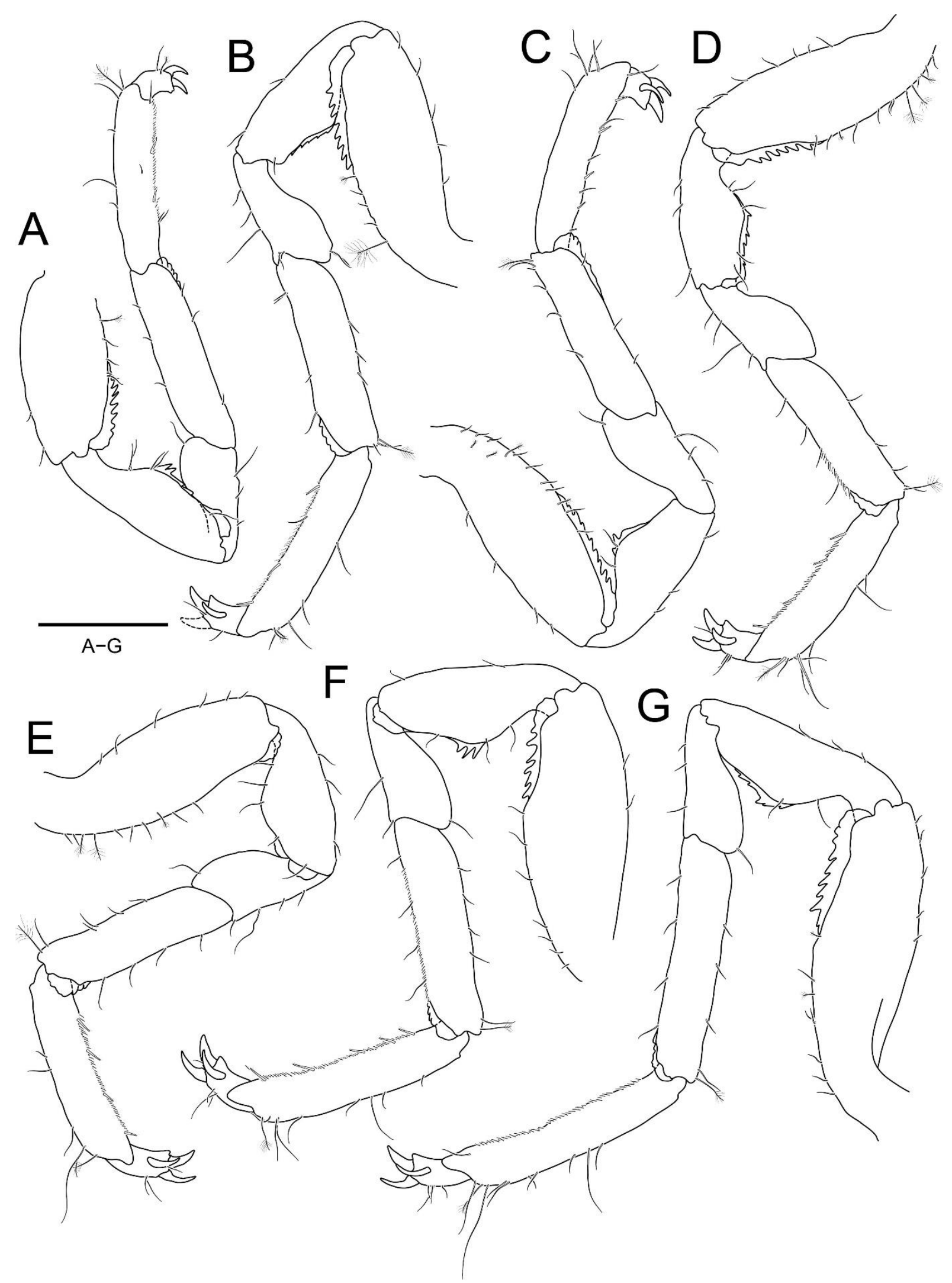




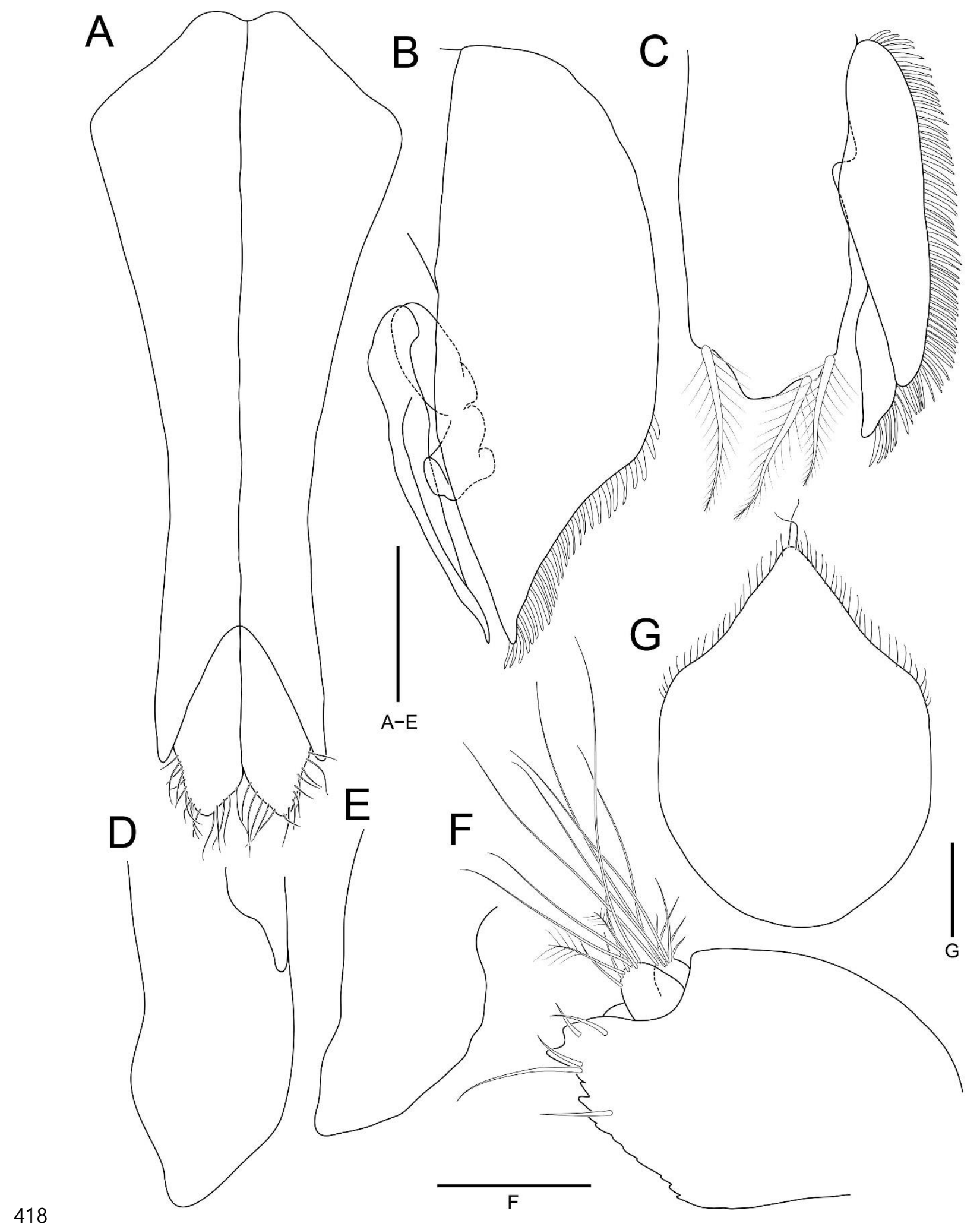

Fig. 4. Kim et al., 2022 


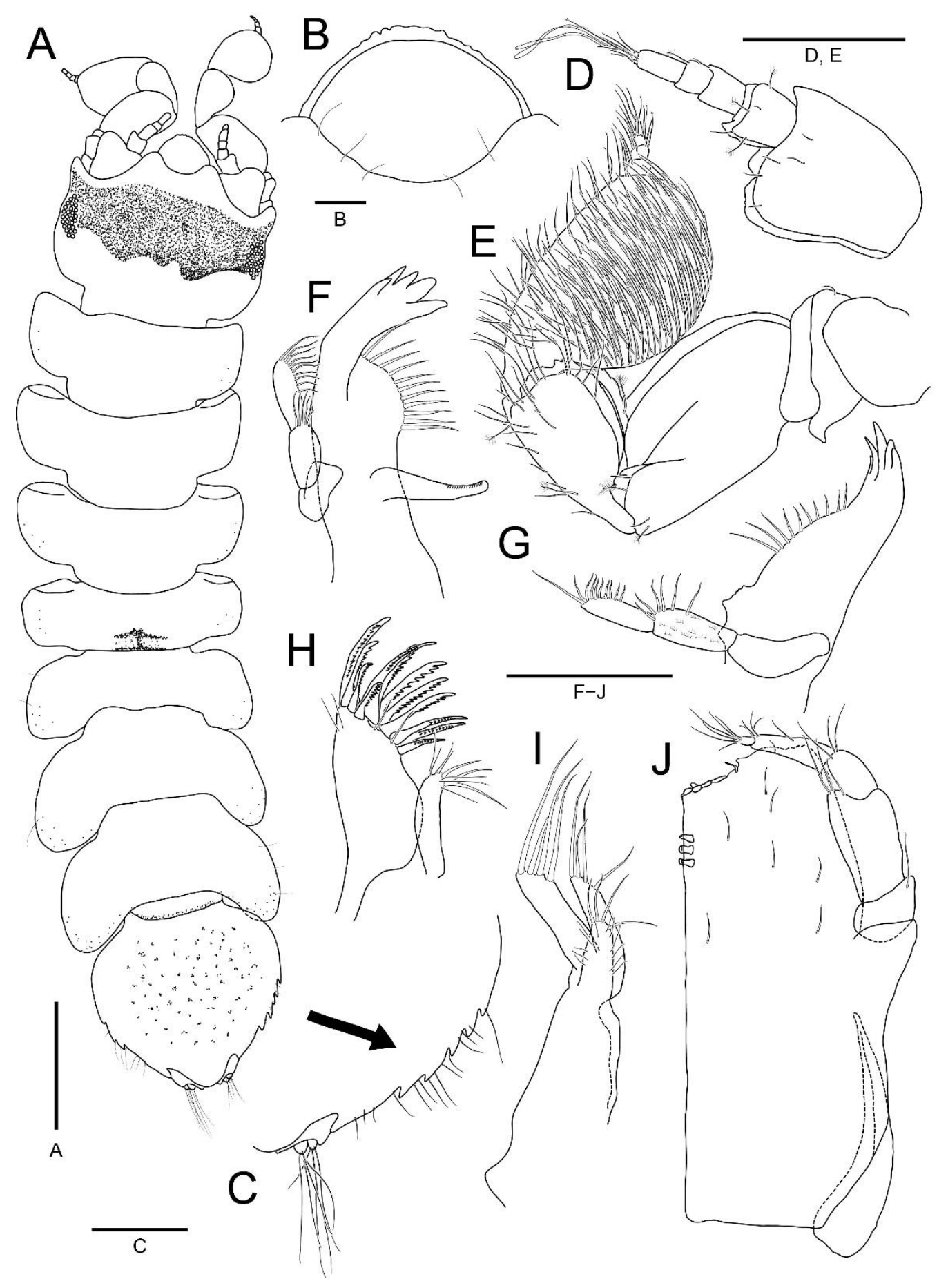




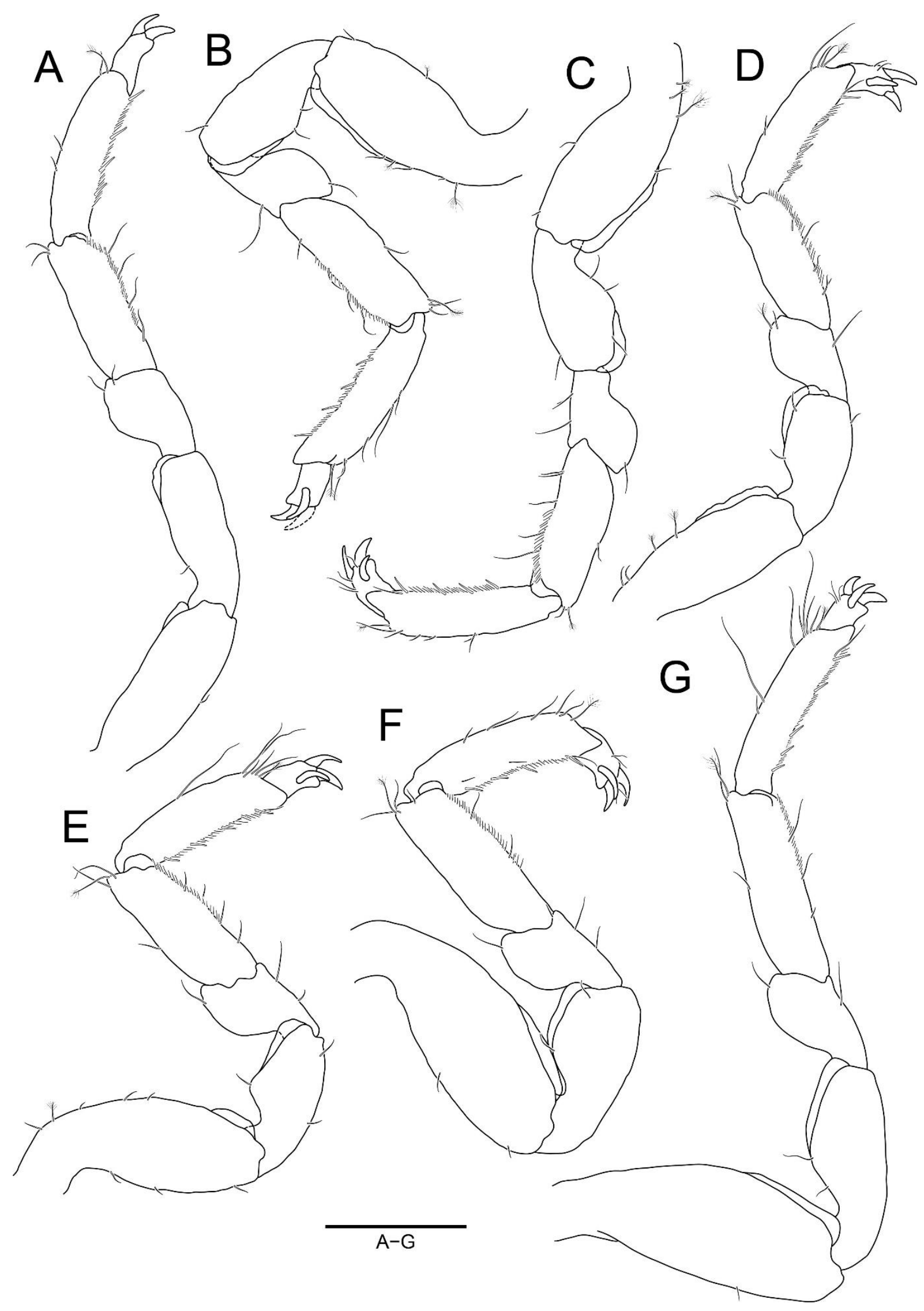




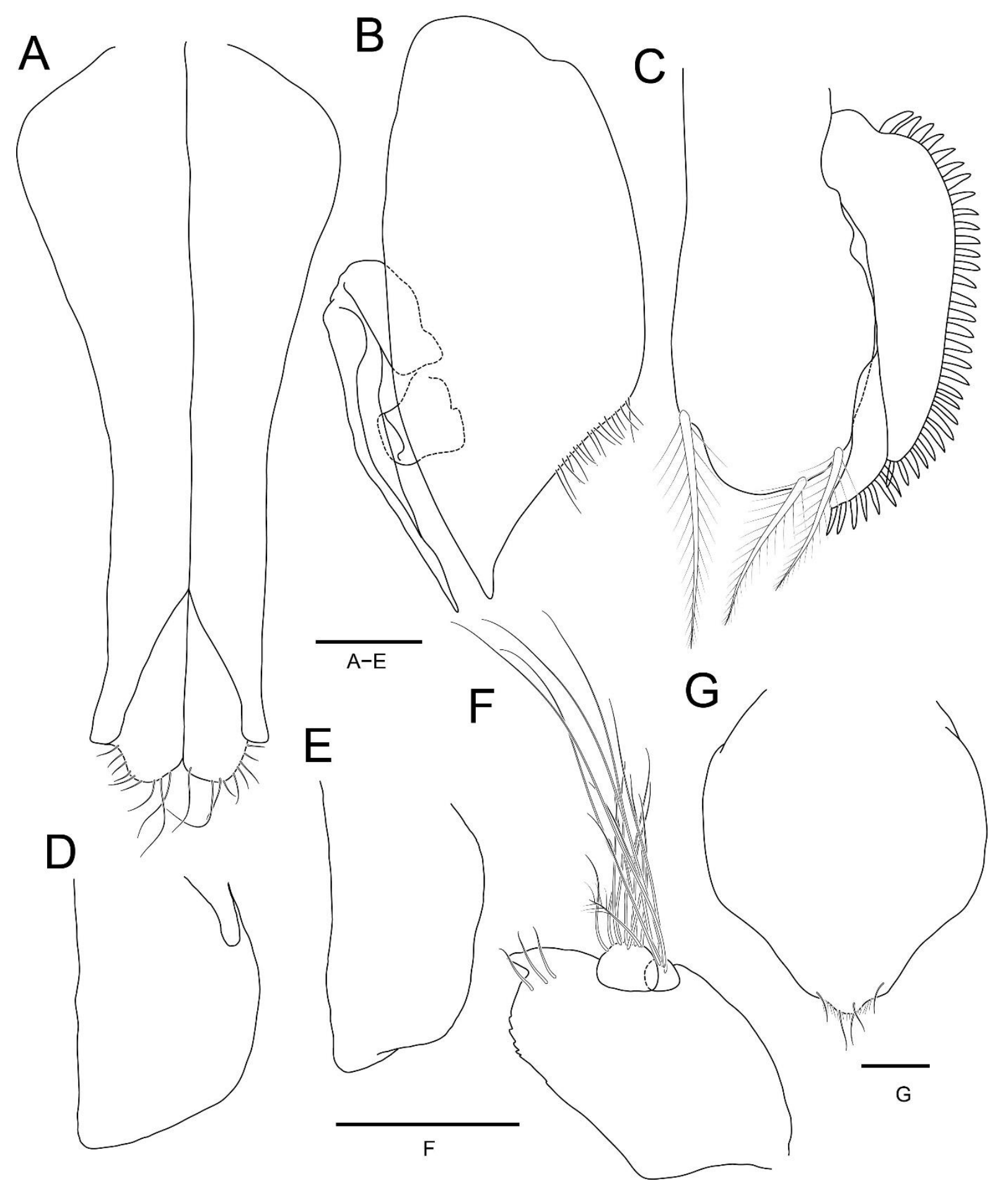

Fig. 7. Kim et al., 2022 